\title{
Helping Teens Answer the Question "Who Am I?": Gender Role and Identity Development in Male Adolescence through Early Adulthood ${ }^{1}$
}

\author{
Rosemary V. Barnett and Stephanie Bates Galligan²
}

Sixth of a series that explores adolescence in terms of physical, cognitive, social moral, gender, and sexual development, this publication focuses on gender role as it relates to identity development in male adolescents and emerging adults.

The transition from high school to college can be a difficult period of vulnerability for youth. During this time, youth are also transitioning from adolescence to their next developmental period, emerging adulthood (ages 18-25). The ability to navigate these transitions is commonly referred to as resilience, a quality that helps youth "bounce back" from risky situations or negative events. We propose that conflict with gender roles may affect resilience in this population, specifically in males.

\section{Assessing the Role of Gender Role Conflict}

As adolescents and emerging adults experience developmental transitions (such as the change from high school to college) and identity development at the same time, they may be more vulnerable to gender role conflict. To explore both positive and negative effects of gender role conflict, resiliency was assessed in a study conducted at University of Florida.

Student participants completed a questionnaire in a classroom setting. The Gender Role Conflict Scale (GRCS) assessed gender role conflict in four patterns:

1. Success, Power and Competition (SPC)

2. Restrictive Emotionality (RE)

3. Restrictive Affectionate Behavior Between Men (RABBM)

4. Conflict Between Work and Family Relations (CBWFR)

The Developmental Assets Profile, developed by the Search Institute (2004), assessed resilience in terms of an inventory of developmental assets or qualities that help youth be resilient. This instrument determines the number and types of assets youth have in various categories, including positive identity and support. Demographic information was also included,

1. This document is FCS2297, one of a series of the Family Youth and Community Sciences Department, Florida Cooperative Extension Service, Institute of Food and Agricultural Sciences, University of Florida. Original publication date May 2009. Visit the EDIS Web site at http://edis.ifas.ufl.edu.

2. Rosemary V. Barnett, PhD, associate professor, Department of Family, Youth and Community Sciences, and Stephanie Bates Galligan, third-year law student, Levin College of Law; University of Florida; Gainesville 32611.

The Institute of Food and Agricultural Sciences (IFAS) is an Equal Opportunity Institution authorized to provide research, educational information and other services only to individuals and institutions that function with non-discrimination with respect to race, creed, color, religion, age, disability, sex, sexual orientation, marital status, national origin, political opinions or affiliations. U.S. Department of Agriculture, Cooperative Extension Service, University of Florida, IFAS, Florida A. \& M. University Cooperative Extension Program, and Boards of County Commissioners Cooperating. Millie Ferrer, Interim Dean 
such as age, race, and year in college. Analysis first determined if relationships existed between gender role conflict and resilience. Next, we further explored these relationships. Finally, we determined which relationships were most important in a real-world context. Results showed that the gender role conflict pattern of Restrictive Emotionality had a significant negative effect on resilience in the sample of college males. This means that as males have more anxiety talking about their feelings or expressing emotions, they tend to be less resilient.

The pattern of Success, Power and Competition also affected resilience, but this relationship was positive. Those who experience this type of gender role conflict internalize a drive for achievement. Indicators revealed that as motivation for success increased, the number of reported assets (resilience) also increased.

\section{Implications for Extension Programs, Practitioners, and Parents}

This study has several implications for youth workers, program leaders and parents:

\section{- Encourage the acceptance of emotional} expression among male youth. Parents can be proactive in building a broader sense of self, by encouraging play as a way to explore male and female roles and the open discussion of feelings. Therefore, it is important to discourage strict gender roles related to emotional expression, for example, by exposing children to activities, toys, stories, etc. in which gender roles are not so defined.

- Foster the drive to succeed in males. As males strive to perform well academically and professionally, their resilience builds. This can be supported by parents and practitioners by providing healthy guidelines for including activities in daily routines that allow male youth to build on successes and identify achievable goals.

- Encourage school staff to be more protective of those that do not conform to typical gender roles. Since youth spend a majority of their waking hours in schools, it is important to make this environment friendly to everyone. Anti-hate speech policies, intolerance of ridicule, and assistance from guidance administration may help gender conflicted youth. Additionally, encouraging all youth to engage in activities not usually associated with their gender may help youth explore other interests or understand others' perspectives.

- Talk about gender roles. In college-age men, talking about gender roles and conflict with them have been shown to positively affect at least Restrictive Emotionality (Beatty et al., 2006). Thus, it is important for youth workers to host open discussions on these issues. This will assist both the individuals involved in these transitions and will ensure a more tolerant environment by educating the public at-large about these issues.

- Expose youth to activities across the gender spectrum. This can include programs within residential communities, discussion through clubs or organizations, and demonstrations in student areas, such as a student union. Faculty may even become involved by including activities, discussion, and video on this topic into their curriculum. This increased exposure will educate youth on these issues and help to create a climate of tolerance.

- Get the information out there. Training in hate speech identification, how to handle tough situations, and distributing appropriate information would help to create a climate in which rigid gender roles do not necessarily translate to decreased resilience. These programs may include youth workers, organizational leaders, teachers, coaches, peer mediators and mentors, guidance counselors, and other administrators. By creating a more accepting environment, we may improve problems with bullying, absenteeism, school safety, and victimization.

\section{Conclusion}

Gender development can be a difficult process for those who do not conform to typical gender roles. It is therefore the responsibility of youth workers to soften the rigid lines separating male and female. By recognizing that gender roles are not as clearly 
defined as in past generations, youth workers and parents can assist youth by educating and exposing them to different interpretations of gender throughout their young lives. This allows practitioners to build potential for positive youth development for all youth, not just those with obvious problems or risk factors. In so doing, perhaps then gender role conflict can be lessened, and more youth may in turn be better equipped with the resilience that, today, is increasingly required of adolescents and emerging adults.

\section{References \& Resources}

Beatty, A., Syzdek, M., \& Bakkum, A. (2006). The Saint John's experience project: challenging men's perceptions of normative gender role conflict. Journal of Men's Studies, 14(3), 322-326.

Galambos, N. \& Leadbeater, B. (2000). Trends in adolescent research for the new millennium.

International Journal of Behavioral Development, 24(3), 289-294.

Galligan, S.B., Barnett, R.V., Brennan, M.A., \& Israel, G.D. (2009). The Effects of Gender Role Conflict on Adolescent and Emerging Adult Male Resiliency. Journal of Mens Studies. (In press.)

O'Neil, J., Good, G., \& Holmes, S. (1995). In R. Levant \& W Pollack (Eds.). The New Psychology of Men. New York: Basic Books. 